Review

\title{
Cryptic Constituents: The Paradox of High Flux-Low Concentration Components of Aquatic Ecosystems
}

\author{
Malin Olofsson ${ }^{1, *(\mathbb{C})}$, Mary E. Power ${ }^{2}$, David A. Stahl ${ }^{3}$, Yvonne Vadeboncoeur ${ }^{4}$ and Michael T. Brett $^{3}$ \\ 1 Department of Aquatic Sciences and Assessment, Swedish University of Agricultural Sciences, \\ 75007 Uppsala, Sweden \\ 2 Department of Integrative Biology, University of California, Berkeley, CA 94720, USA; \\ mepower@berkeley.edu \\ 3 Department of Civil and Environmental Engineering, University of Washington, Seattle, WA 98195, USA; \\ dastahl@uw.edu (D.A.S.); mtbrett@uw.edu (M.T.B.) \\ 4 Department of Biological Sciences, Wright State University, Dayton, OH 45435, USA; \\ yvonne.vadeboncoeur@wright.edu \\ * Correspondence: malin.olofsson@slu.se
}

Citation: Olofsson, M.; Power, M.E.; Stahl, D.A.; Vadeboncoeur, Y.; Brett, M.T. Cryptic Constituents: The Paradox of High Flux-Low Concentration Components of Aquatic Ecosystems. Water 2021, 13, 2301. https://doi.org/10.3390/ w13162301

Academic Editor: Kun Shi

Received: 9 July 2021

Accepted: 18 August 2021

Published: 22 August 2021

Publisher's Note: MDPI stays neutral with regard to jurisdictional claims in published maps and institutional affiliations.

Copyright: (c) 2021 by the authors. Licensee MDPI, Basel, Switzerland. This article is an open access article distributed under the terms and conditions of the Creative Commons Attribution (CC BY) license (https:// creativecommons.org/licenses/by/ $4.0 /)$.

\begin{abstract}
The interface between terrestrial ecosystems and inland waters is an important link in the global carbon cycle. However, the extent to which allochthonous organic matter entering freshwater systems plays a major role in microbial and higher-trophic-level processes is under debate. Human perturbations can alter fluxes of terrestrial carbon to aquatic environments in complex ways. The biomass and production of aquatic microbes are traditionally thought to be resource limited via stoichiometric constraints such as nutrient ratios or the carbon standing stock at a given timepoint. Low concentrations of a particular constituent, however, can be strong evidence of its importance in food webs. High fluxes of a constituent are often associated with low concentrations due to high uptake rates, particularly in aquatic food webs. A focus on biomass rather than turnover can lead investigators to misconstrue dissolved organic carbon use by bacteria. By combining tracer methods with mass balance calculations, we reveal hidden patterns in aquatic ecosystems that emphasize fluxes, turnover rates, and molecular interactions. We suggest that this approach will improve forecasts of aquatic ecosystem responses to warming or altered nitrogen usage.
\end{abstract}

Keywords: turnover rates; inorganic nutrients; carbon; nitrogen; primary production

\section{Introduction}

Aquatic primary producers perform $50 \%$ of global carbon fixation [1], of which half is directly used by heterotrophic bacteria [2]. Limitations of phytoplankton and bacterial biomass and production have traditionally been considered to be constrained by fixed stoichiometric ratios, i.e., Redfield ratios and/or measured carbon concentrations. However, since many important resources are found at low concentrations with high turnover, measurements of pool sizes or magnitudes may not reveal the degree to which organisms are limited by the rates of resource supply.

There are many situations where the actual use of important constituents does not fit into fixed ratios or traditional food web paradigms. For example, based on its abundance, terrestrially derived dissolved organic carbon (t-DOC) in lakes may appear to be the primary resource available for heterotrophic bacteria, unless turnover rates and DOC bioavailability are considered. Similarly, when only a few species of phytoplankton dominate primary producer biomass, often, these species are not those preferred by grazers [3]. If consumers limit these resources, the high abundance of organic molecules or dominant primary producers are evidence of their lack of importance in food webs, rather than the reverse. Consumer control over producers or detritus can be cryptic in aquatic ecosystems.

Here, we show five pathways in which key constituents are found in low concentrations owing to high demand and high flux rates: DOC metabolism in lakes, pelagic 
and benthic grazing patterns, ammonium utilization, and nitrite transformation. We also suggest procedures for tracing these hidden constituents through ecosystems by combining methods, for example stable isotope labeling with mass balance calculations, to trace fluxes and actual consumption, in order to elucidate organism interactions in greater detail.

\section{Carbon Cycling in Aquatic Environments}

\subsection{Dissolved Organic Carbon Metabolism}

The importance of quantifying and tracing DOC fluxes through aquatic ecosystems is increasingly recognized [4-6]. Many limnologists have claimed that terrestrially-derived DOC (t-DOC) plays a very large role in the "metabolism" of lakes because t-DOC is often the largest pool of organic matter in their water columns [7-9]. However, from a mass balance perspective, a high concentration of a constituent in a reactor (or a lake) is strong evidence that that constituent has very low reactivity and thus plays only a minor role in the metabolism of the system [10].

We modeled bacterial processing of $\mathrm{t}-\mathrm{DOC}$ and autochthonous primary producer derived DOC (PPr-DOC) in a hypothetical "Median Lake" (Figure 1, Table 1, and Supplementary Calculations). Median Lake has the median hydraulic residence time (HRT) for 305 lakes ([11]; Table 1), the median t-DOC loading for 20 lakes [10], and the median pelagic plus benthic autochthonous gross primary production (PPr) for 58 lakes [10]. We assume the flux of PPr-DOC is ca. 25\% of gross primary production [12,13], t-DOC is degraded at $0.1 \% \mathrm{~d}^{-1}[4,10]$, and PPr-DOC is broken down at $10 \% \mathrm{~d}^{-1}$ ([12]; page 512). We calculate DOC removal from the water based on the conventional "continuously mixed tank reactor" mass balance equations [11] accordingly: Retention $=\left(\mathrm{DOC}_{\mathrm{IN}}-\mathrm{DOC}_{\mathrm{OUT}}\right) / \mathrm{DOC}_{\mathrm{IN}}=1$ $-\left(\mathrm{DOC}_{\mathrm{OUT}} / \mathrm{DOC}_{\mathrm{IN}}\right)=\sigma /(\sigma+\rho)$, where $\sigma$ represents the first-order rate constant for the degradation or removal of DOC from the water and $\rho$ represents the advective flushing of water from the reactor (or lake in this case), i.e., $\rho=\mathrm{HRT}^{-1}$. For example, if a lake had an input DOC concentration of $15 \mathrm{mg} \mathrm{C} \mathrm{L}^{-1}$ and an output DOC concentration of $6 \mathrm{mg} \mathrm{L}^{-1}$, $60 \%$ of the DOC was removed in the lake and $40 \%$ was advected with the lake outflows. Removal in a lake could be due to microbial or photochemical oxidation, or flocculation and accumulation in the lake sediments $[10,14]$. Because the lake is assumed to be well mixed, the fraction of DOC that persists in the lake water represents the DOC that will ultimately be advected from the lake. For Median Lake, the example above results in nearly identical inputs of t-DOC and PPr-DOC, i.e., 62 and $63 \mathrm{mg} \mathrm{C} \mathrm{m}^{-2} \mathrm{~d}^{-1}$, respectively (Table 1). For a lake with a $0.6 \mathrm{yr}$ HRT, $18 \%$ of the t-DOC and $96 \%$ of the PPr-DOC fluxes are removed from the lake water via biological uptake. Of the total amount of DOC removed, $84 \%$ originated from PPr-DOC and 16\% from t-DOC. Of the remaining DOC, i.e., the fraction that is still present in the water and will ultimately be advected, $5 \%$ originated from PPr-DOC and $95 \%$ from $t$-DOC inputs.

If we further assume that algal-derived DOC supports bacterial production with a bacterial growth efficiency (BGE) of 0.5 and t-DOC has a BGE of 0.1 [15], we can calculate the proportion of bacterial production supported by these two sources, which is equivalent to the (flux of DOC)*Removal*BGE (Table 1). This shows that $96 \%$ of the bacterial production in the lake was supported by algal exudates and only $4 \%$ was supported by terrestrial inputs. In reality, t-DOC support of bacterial production in this hypothetical lake would likely be smaller because a substantial fraction of t-DOC inputs to lakes may flocculate and accumulate in the sediments [14]. Thus, the constituent that is present at high concentrations in Median Lake (i.e., t-DOC) is far less important for bacterial metabolism than the constituent present at much lower concentrations (i.e., PPr-DOC), despite both having very similar mass fluxes. Hence, the cryptic constituent has the greatest impact on the biogeochemistry and the food web of the lake. 


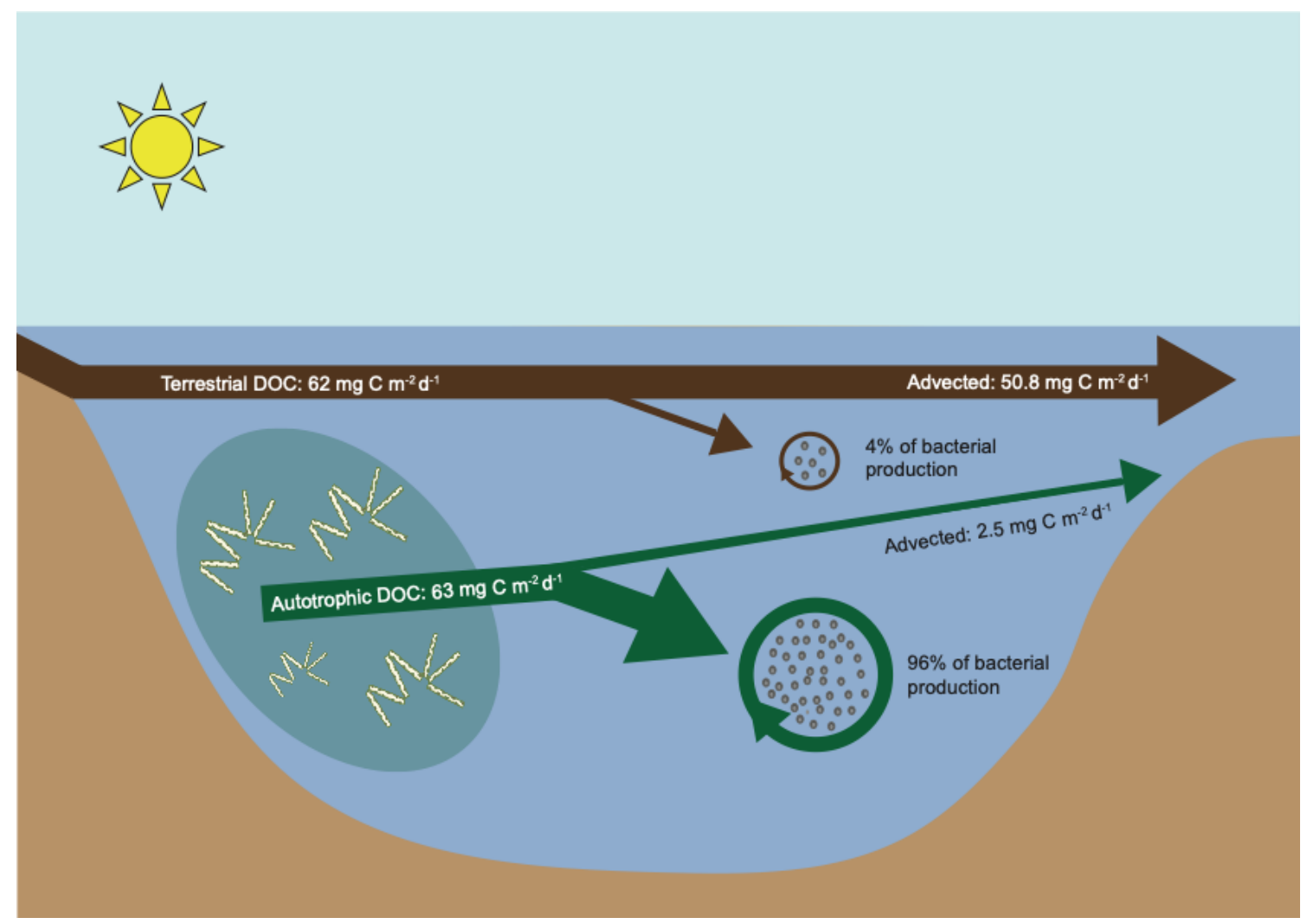

Figure 1. A schematic image of the "Median Lake" including terrestrially-derived dissolved organic carbon (DOC) and DOC released from autotrophic primary producers. The terrestrially-derived carbon supports $4 \%$ of the bacterial production whereas autotrophic derived DOC supports $96 \%$. See Table 1 for details.

Table 1. Calculations of the dissolved organic carbon (DOC) metabolism in the "Median" lake. The table includes parameter, unit, primary production (PPr) and terrestrially-derived carbon, and reference for the value or the calculation from where it was derived.

\begin{tabular}{|c|c|c|c|c|}
\hline Parameter & Unit & PPr & Terrestrial & Reference/Derived from \\
\hline Benthic and pelagic PPr & $\operatorname{mg} C\left(\mathrm{~m}^{-2} \mathrm{~d}^{-1}\right)$ & 253 & - & Brett et al. [10] \\
\hline Bacterial growth efficiency (BGE) & biomass produced/mass ingested & 0.5 & 0.1 & del Giorgio and Cole [15] \\
\hline DOC loading & $\operatorname{mgC}\left(\mathrm{m}^{-2} \mathrm{~d}^{-1}\right)$ & 63 & 62 & Brett et al. [10] \\
\hline DOC first-order loss rate $(\sigma)$ & $d^{-1}$ & 0.1 & 0.001 & $\begin{array}{l}\text { Hanson et al. [4]; Brett et al. [10]; } \\
\text { Wetzel [12] }\end{array}$ \\
\hline HRT & yrs & 0.6 & 0.6 & Brett and Benjamin [11] \\
\hline Flushing rate $(\rho)$ & $\mathrm{d}^{-1}$ & 0.005 & 0.005 & Brett and Benjamin [11] \\
\hline Areal hydrologic loading & $\mathrm{LC}\left(\mathrm{m}^{-2} \mathrm{~d}^{-1}\right)$ & - & 5 & Brett and Benjamin [11] \\
\hline Removal & unitless & 0.96 & 0.18 & $\sigma /(\sigma+\rho)$ \\
\hline Removed & $\operatorname{mg} C\left(m^{-2} d^{-1}\right)$ & 60.5 & 11.2 & DOC load Removal \\
\hline Percent metabolized & $\%$ & 84 & 16 & Removed $/ \sum$ Removed 100 \\
\hline Remaining DOC flux & $\operatorname{mg} C\left(\mathrm{~m}^{-2} \mathrm{~d}^{-1}\right)$ & 2.5 & 50.8 & DOC load-Removed \\
\hline DOC concentration remaining & $\operatorname{mg~C~L~}{ }^{-1}$ & 0.5 & 10.1 & Remaining/areal load \\
\hline Percent remaining & $\%$ & 5 & 95 & DOC conc. $/ \sum$ DOC conc. 100 \\
\hline Bacteria production from DOC & $\operatorname{mgC}\left(\mathrm{m}^{-2} \mathrm{~d}^{-1}\right)$ & 30.2 & 1.1 & DOC load Removal BGE \\
\hline Bacteria production from $\mathrm{DOC} \%$ & $\%$ & 96 & 4 & Bact. prod. $/ \sum$ Bact. prod. 100 \\
\hline
\end{tabular}




\subsection{Cryptic Grazing-Pelagic Ecosystems}

Selective grazing can result in high-quality food being present at very low concentrations in aquatic ecosystems. Therefore, key food taxa with low abundances may be major players for grazers and in nutrient cycling. In a field study, Olofsson et al. [16] showed that the importance of chain-forming diatoms in food webs outweighed their biomass representation because they were highly grazed and/or fast-sinking, resulting in a low abundance. Governed by grazing patterns, phytoplankton abundance and areal primary production rates can be inversely related across seasons in temperate waters [17]. In enriched ecosystems, e.g., upwelling areas or highly eutrophic areas, less palatable or less nutritious phytoplankton species may dominate biomass, with very low concentrations of the higher-quality resources. An intriguing example includes massive blooms of the filamentous cyanobacteria Aphanizomenon flos-aquae co-occurring with Daphnia pulicaria (Figure 2). At first, one might presume that Daphnia mainly feed on the cyanobacteria, but in the laboratory, all Daphnia die after only a few days if this is the sole food resource (Brett et al. unpubl.). The fatty acid composition of Daphnia [18], indicated that only $40 \%$ of the Daphnia resources came from Aphanizomenon and the rest came from cryptophytes and diatoms (Brett et al. unpubl.). Cryptophytes and diatoms are known to be high-quality food for Daphnia [19], but they represent $<2 \%$ of the total phytoplankton biomass in Upper Klamath Lake during the cyanobacteria-dominated summer months. This suggests Daphnia may feed very selectively on the diatoms and cryptophytes, whose rarity might otherwise suggest that they do not play a major role in this lake. Additionally, Aphanizomenon may interfere with predation on Daphnia by zooplanktivorous fish by reducing water clarity, and therefore allowing the grazer to reach very high biomass.

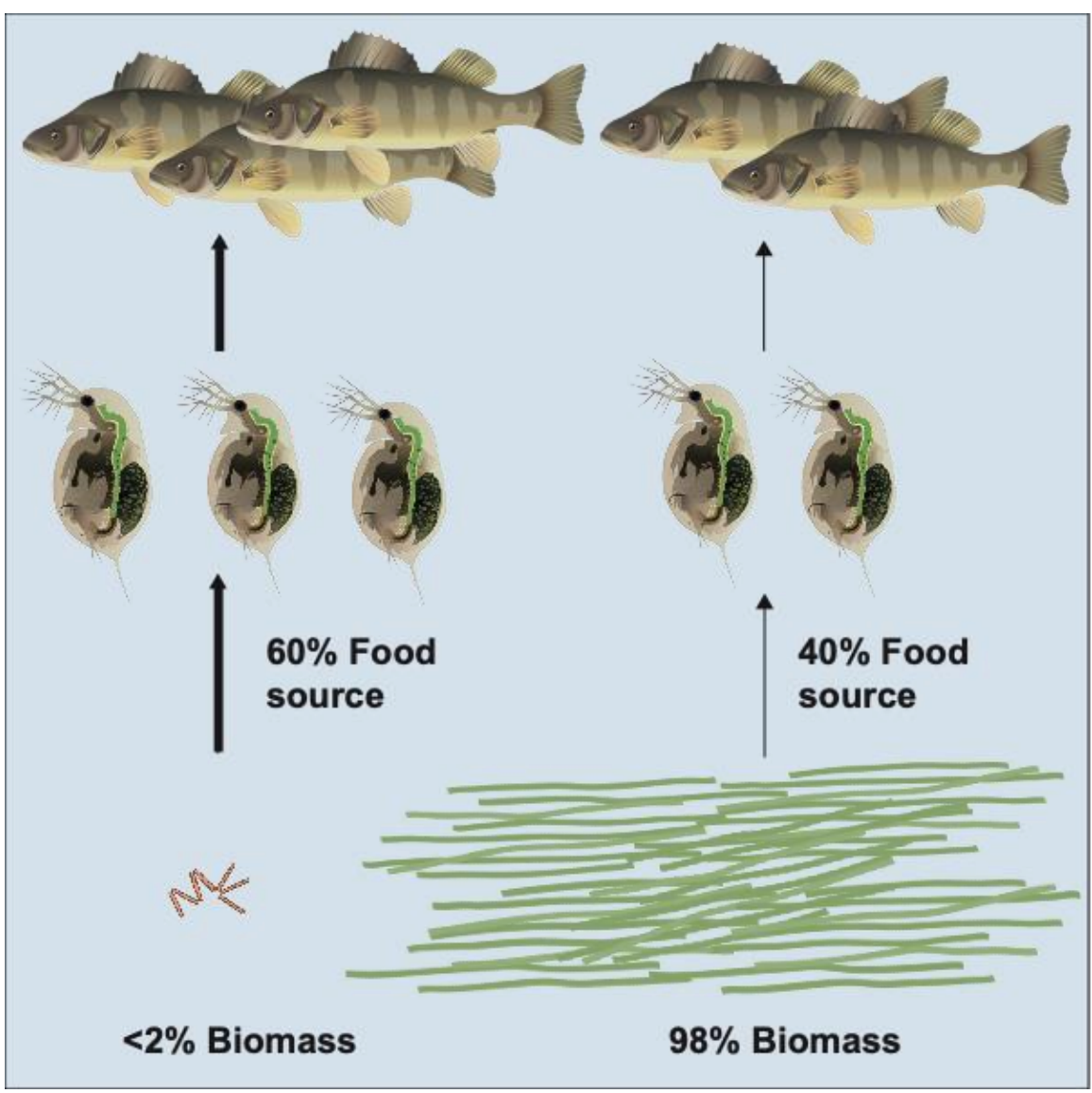

Figure 2. Schematic drawing of an ecosystem dominated by Aphanizomenon and Daphnia. Although it appears that Daphnia is feeding on Aphanizomenon, fatty acid analyses of Daphnia reveals that $60 \%$ of the food came from cryptophytes and diatoms which constitute less than $2 \%$ of the total standing phytoplankton biomass. 
Similarly, during the summer in the brackish Baltic Sea filamentous cyanobacteria may account for more than half of the carbon biomass [20] but they are generally avoided by grazers [3] and again diatoms are found in low abundance and are potentially highly grazed. Further complicating grazing patterns, mixotrophic organisms can be both primary producers and grazers, depending on resource availability. Mixotrophy increases the likelihood that standing stocks and nutrient concentrations will not reveal the flux directions of an ecosystem, as they can shift between autotrophy and bacterial predation, thus responding to small shifts in the relative ratio of resources, which can boost primary production by up to $50 \%$ in oligotrophic areas [21]. Methods that track actual consumption using, for example, fatty acids or stable isotope tracers at a single-cell level [22-24] are necessary to reveal such cryptic trophic connections.

\subsection{Cryptic Grazing in Benthic Food Webs}

Grazer selectivity and high consumption efficiency can substantially reduce the abundance of a high-quality food in aquatic ecosystems. Preferred taxa can be present at low abundance while maintaining high productivity and serving as the trophic foundation for aquatic ecosystems. Benthic food webs of many streams and lakes are supported by thin veneers of highly nutritious diatoms [25]. Diatom-dominated biofilms are intensely grazed by zoobenthic invertebrates and fish. Grazing alleviates nutrient and light limitation of the remaining algae, resulting in high biomass-specific as well as areal primary production [26] In addition to depressing biomass, grazing increases nutrient turnover [27]. Because benthic consumers track primary producer availability, their grazing can result in uniformly low algal biomass even across strong contrasts in environmental productivity $[28,29]$, particularly for the benthic algal groups that are preferentially grazed. However, compared to phytoplankton communities (which are dispersed throughout the euphotic zone), benthic biofilms are a spatially concentrated food. Concentrated benthic algae support energy demands of grazers ranging in size from infaunal microscopic protozoans to large mobile algivorous fish. Critically, benthic algal carbon is efficiently incorporated into lake food webs because grazing zoobenthic insects are orders of magnitude larger than zooplankton and are an important intermediary food source for predatory fish that undergo ontogenetic diet and habitat shifts [30,31], or feed from both littoral and pelagic food chains [32].

Macrophytes and filamentous algae are conspicuous structural components of benthic, nearshore habitats, but they generally enter the food web primarily through slow-turnover, detrital pathways rather than direct consumption by grazers [33]. Filamentous green algae and macrophytes contain structural compounds such as cellulose that are difficult to digest. Studies have shown that a high proportion of filamentous green algae can pass through the guts of benthic grazers intact, whereas less than $10 \%$ of diatoms pass through consumer guts intact [34]. Like the filamentous green algae, terrestrial leaf litter has a very high content of carbon-rich lignocellulose, which makes this organic matter quite difficult for benthic grazers to digest and assimilate [5]. In an experimental addition of terrestrial maize leaves to two lakes with contrasting autotrophic structure (phytoplankton versus macrophyte dominated), the maize was entrained only into the benthic food web of the macrophyte-dominated lake, which already supported a guild of shredding macroinvertebrates. Although the researchers detected a signal of the isotopically distinct maize in the zoobenthos, they concluded that it made a rather ephemeral, minor contribution ( 1 and $11 \%$ of carbon flow to zoobenthic production of the phytoplankton vs. macrophyte dominated lakes, respectively) [35].

One of the most important roles that filamentous green algae, terrestrial leaf litter and large woody debris may play in stream ecosystems is as a bioactive surface where more edible and nutritious diatoms can grow [25,36,37]. Epiphytic diatoms can smother host algae like Cladophora or its relative Rhizoclonium, rendering these assemblages highly palatable and nutritious for vertebrate and invertebrate grazers [29,38,39]. Fatty acid analyses of stream invertebrates indicate preferential reliance on diatoms and other benthic algae, even in cases where other potential food resources (e.g., filamentous green algae and 
terrestrial organic matter) are present at much higher concentrations. Eicosapentaenoic acid (EPA; 20:5w3) was one of the most abundant fatty acid molecules in nearly all benthic invertebrates sampled $[40,41]$. EPA is not synthesized by terrestrial vegetation, green algae or cyanobacteria, but this essential fatty acid is one of the most abundant fatty acids synthesized by diatoms and is a highly informative biomarker for diatom consumption [5]. As concluded by Vadeboncoeur and Power [25] "interactions of attached algae and grazers often produce ecosystems that are characterized by a highly productive, low biomass (cryptic) algal production that is efficiently transferred to primary consumers".

\section{Nitrogen Limitation}

\subsection{Ammonium Utilization}

Ammonium is quickly turned over in aquatic ecosystems [42], and therefore, it does not constitute a large fraction of the global nitrogen pool [43]. However, ammonium can still drive up to $95 \%$ of the primary production in oligotrophic areas, even when concentrations are low [44]. Therefore, the absolute concentration of ammonium does not reflect its actual availability; concentrations can be very low and stable over time, even though turnover times are as rapid as only a few hours [16,45]. Since the recent introduction to biological oceanography of single-cell measurements using secondary ion mass spectrometry (SIMS) [46], field surveys have revealed intriguing species-specific nutrient fluxes in mixed populations under in situ conditions [16,45,47]. By combining SIMS and bulk measurements with small-scale mass balance calculations of diffusion it was demonstrated that turbulence can increase nutrient availability for large chain-forming diatoms by up to 60\% [47]. This cryptic pathway would be overlooked if only one of the two methods described were applied.

Olofsson et al. found that ammonium concentration remained stable at $\sim 200 \mathrm{nM}$ during a $5 \mathrm{~h}$ incubation of a mixed phytoplankton late summer bloom community [16]. Using SIMS, the ammonium assimilation measured in a single diatom cell of Chaetoceros was equal to $272 \mathrm{fmol} \mathrm{N}$ cell ${ }^{-1} \mathrm{~h}^{-1}$ in the mixed phytoplankton community. However, the diffusion-limited ammonium supply to the chain-forming diatom, calculated based on mass transfer theory, was $62 \mathrm{fmol} \mathrm{N}$ cell ${ }^{-1} \mathrm{~h}^{-1}$ (assuming diffusion to a cylinder; $10 \mu \mathrm{m}$ in diameter, $23 \mu \mathrm{m}$ in cell length, and 7.9 cells chain $^{-1}$, calculated based on Clift et at. [48]). Thus, the large diatoms assimilated ammonium at 4 -fold the rate of the theoretically predicted diffusion-limited supply [16]. With relatively low measured turbulence in this system it could only explain $10 \%$ of the deviation. It has instead been hypothesized that microbial activities within the phycosphere alleviate nutrient limitation for the large diatoms (Figure 3), a cryptic phenomenon that needs further attention [49] but would be sufficient to explain the disparity [16].

Although diatoms constituted only $6 \%$ the Baltic Sea phytoplankton community biomass, they accounted for a large share of the inorganic carbon and nitrogen consumption (20-54\% out of the bulk measurements). This disproportionate relationship between standing biomass and inorganic nutrient assimilation by large chain-forming diatoms was revealed only by using the dual approach of both single-cell and bulk measurements [16]. If only standing stocks of diatoms or the absolute concentration of ammonium were considered, one would not expect diatoms to be important except during spring blooms, when they appear in high abundances and nitrate is readily available. New tools and methods will help decipher hidden turnover processes, critically important for projecting ecosystem consequences of future elevated use by cells of regenerated nutrients, e.g., ammonium [50]. By only quantifying absolute concentrations of ammonium, small-scale continuous fluxes between key groups in the microbial world are underestimated. 


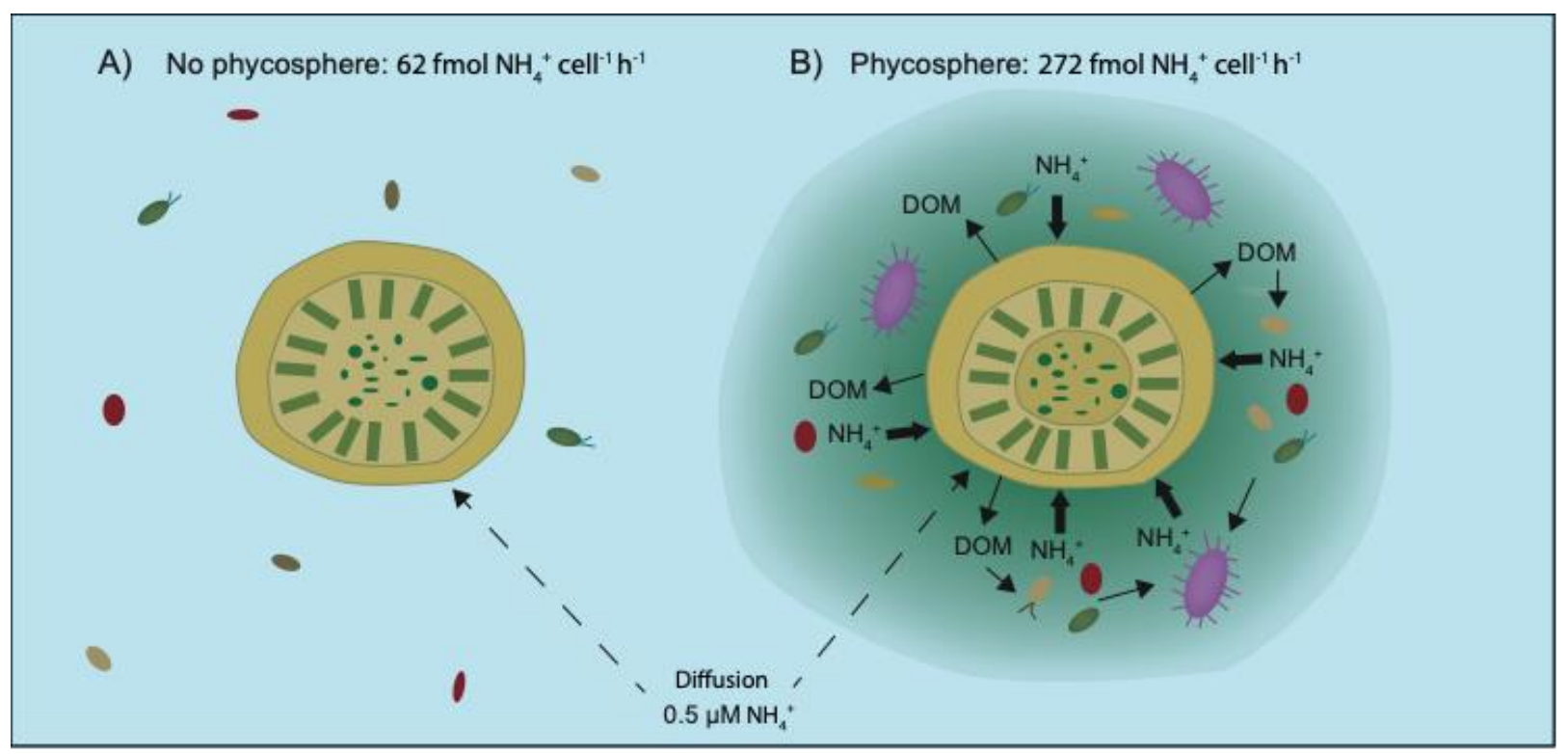

Figure 3. Schematic image of ammonium $\left(\mathrm{NH}_{4}{ }^{+}\right.$) assimilation via (A), diffusion only and (B), diffusion plus microbial interactions within the phycosphere. In panel B, bacterial recycling of dissolved organic matter (DOM) released by the diatom and protozoa grazing on bacteria together largely increase the ammonium availability, creating a gradient of elevated ammonium concentration around the diatom cell, decreasing with distance from the surface. Drawn based on results from Olofsson et al. [16].

\subsection{Nitrite Transformation}

Nitrite can also have a very low concentration but a high flux rate [51] because it is rapidly consumed as an intermediate in aerobic and anaerobic processes. Nitrite rarely accumulates in the environment except when the normal homeostasis of the oxidative and reductive pathways is disrupted [51]. During nitrification, ammonia-oxidizing microorganisms (both bacteria and archaea) convert ammonia to nitrite. Subsequently, nitrite-oxidizing bacteria convert nitrite to nitrate. In the absence of oxygen, nitrite is formed by reduction of nitrate to nitrite, the first step in denitrification, before being further reduced to nitric oxide and ultimately to $\mathrm{N}_{2} \mathrm{O}$ or $\mathrm{N}_{2}$. Nitrite can also be consumed as a resource in anaerobic ammonia oxidation [52]. Nitrification is commonly not detected in surface waters because nitrifiers are unable to compete with phytoplankton for ammonia and nitrite [16]. When phytoplankton growth is limited by something other than nitrogen, such as lower light, nitrifying microbes may locally sustain high rates of ammonia oxidation [53].

Although nitrite does not accumulate in surface waters, the high average concentration of nitrate in many lakes, rivers and parts of the ocean is unequivocal evidence for the importance of nitrite metabolism in these systems. Except for some atmospheric deposition, nearly all nitrate in aquatic ecosystems is derived from the oxidation of nitrite. For example, ammonium concentrations in the rivers that drain to an estuary of the Puget Sound averaged $0.68 \mu \mathrm{M}$, nitrite averaged $0.086 \mu \mathrm{M}$, and nitrate concentrations averaged $6.9 \mu \mathrm{M}$ [54]. The fact that the resource is on average 8-fold, and the end-product is 80 -fold, more concentrated than nitrite indicates very rapid processing of nitrite. Since natural settings where nitrite does accumulate are relatively rare, they illustrate the normally tight coupling of nitrite as a transient intermediate in the high flux of reactive nitrogen species through oxidative and reductive processes. Due to its high turnover rates and low concentrations, nitrification can be hard to measure. Recent advances, however, include stable isotope tracing experiments using labelled ammonium or nitrite [55,56]. Recently, additions of labelled ammonium to an ice-covered lake revealed ammonia oxidation rates ranging from undetectable to up to $333 \mathrm{nmol} \mathrm{L}^{-1} \mathrm{~d}^{-1}$ [57]. Indications of high nitrification rates during winter in low light environments, as well as by archaea in near surface wa- 
ters [58] and in ammonium-poor regions of the ocean [59], demonstrate the need to better characterize nitrite fluxes, as these may be more important than previously realized.

\section{Conclusions and Future Implications}

In response to changing land use, atmospheric acid deposition, and climate change [60], inland waters in northern Europe and North America have undergone increased brownification (elevated DOC concentrations) during recent decades [61,62], which in turn has altered their community structure, water quality, light availability, and productivity. These ecosystem changes appear, in some cases, to have reduced overall productivity, with less nutritious lake food webs and negative consequences for higher trophic levels [6]. There are conflicting reports, however, that elevated allochthonous DOM loads have increased and decreased both phytoplankton and zooplankton productivity [5]. Further studies quantifying these processes are needed to understand potential threats and project the future of these ecosystems. Again, the absolute availability of a component can be a misleading indicator of its role in ecosystem function. Rather, we need to quantify turnover times and resource use to avoid underestimating importance due to low concentrations. We have shown several important scenarios in which high turnover resources seem almost invisible, until tracing and mass balance methods are applied to reveal their impacts and importance.

As climate change and other anthropogenic impacts increasingly stress our planet, we also need to detect the cryptic constituents that support microbial processes in aquatic ecosystems [63]. For example, poorly understood direct and indirect trophic links between bacteria and phytoplankton account for $\sim 25 \%$ of global net primary production $[64,65]$, and the importance of carbon fluxes they mediate will accelerate with elevated temperatures [66]. High turnover rates and low concentration of the phytoplankton-derived labile carbon compounds further complicate the understanding, at times supposedly directed by bacterial release of vitamins [67] and/or hormones [68]. Traditional ways of monitoring ecosystems by focusing on concentrations or biomass often lead to significant underestimation of the actual importance of sparse substrates with high turnover rates. To untangle critical nutrient transport, metabolic, and grazing pathways, we must measure rates and fluxes in addition to absolute values and standing stocks. Better understanding of these constituents and the high fluxes that are associated with them are for example useful for calibrating biogeochemical models with a focus on "process validation" rather than the classic "state validation" [69]. We argue for the use of small- and large-scale mass balance calculations in combination with in situ tracing methods to reveal cryptic resources present at very low concentrations and tightly coupled interactions that are pivotal to ecosystem processes.

Supplementary Materials: The following are available online at https://www.mdpi.com/article/10 .3390/w13162301/s1, calculations on the dissolved organic carbon metabolism in the "Median" lake.

Author Contributions: M.O., M.E.P., D.A.S., Y.V. and M.T.B. jointly pitched the idea of the review. M.O. led the writing of the review, where M.E.P. and Y.V. wrote the section on cryptic grazing within benthic ecosystems, D.A.S. wrote the section on nitrite transformation, M.T.B. wrote the section on dissolved organic carbon metabolism, and M.O. the remaining sections. All authors commented on and edited the draft during the writing process and have approved the final version of the manuscript.

Funding: This research received no external funding.

Data Availability Statement: The discussed data were extracted from the literature.

Acknowledgments: M.O. would like to thank Helle Ploug and Erik Selander for inspiring discussions that have contributed to the draft version of the manuscript. Cartoons were provided with the courtesy of the Integration and Application Network (ian.umces.edu/media-library, accessed on 5 January 2021).

Conflicts of Interest: The authors declare no conflict of interest. 


\section{References}

1. Field, C.B.; Behrenfeld, M.J.; Randerson, J.T.; Falkowski, P. Primary production of the biosphere: Integrating terrestrial and oceanic components. Science 1998, 281, 237-240. [CrossRef]

2. Williams, P.J.I. Heterotrophic bacteria and the dynamics of dissolved organic material. In Microbial Ecology of the Oceans; Kirchman, D.L., Ed.; Wiley-Liss: New York, NY, USA, 2000; pp. 153-200.

3. Karlson, A.; Duberg, J.; Motwani, N.H.; Hogfors, H.; Klawonn, I.; Ploug, H.; Barthel Svedén, J.; Garbaras, A.; Sundelin, B.; Hajdu, S.; et al. Nitrogen fixation by cyanobacteria stimulates production in Baltic food webs. AMBIO 2015, 44, S413-S426. [CrossRef]

4. Hanson, P.C.; Hamilton, D.P.; Stanley, E.H.; Preston, N.; Langman, O.C.; Kara, E.L. Fate of allochthonous dissolved organic carbon in lakes: A quantitative approach. PLoS ONE 2011, 6, e21884. [CrossRef]

5. Brett, M.T.; Bunn, S.E.; Chandra, S.; Galloway, A.W.E.; Guo, F.; Kainz, M.J.; Kankaala, P.; Lau, D.C.P.; Moulton, T.P.; Power, M.E.; et al. How important are terrestrial organic carbon inputs for secondary production in freshwater ecosystems? Freshw. Biol. 2017, 62, 833-853. [CrossRef]

6. Creed, I.F.; Bergström, A.-K.; Trick, C.G.; Grimm, N.B.; Hessen, D.O.; Karlsson, J.; Kidd, K.A.; Kritzberg, E.; McKnight, D.M.; Freeman, E.C.; et al. Global change-driven effects on dissolved organic matter composition: Implications for food webs of northern lakes. Glob. Chang. Biol. 2018, 24, 3692-3714. [CrossRef] [PubMed]

7. Wetzel, R.G. Death, detritus and energy flow in aquatic ecosystems. Freshwat. Biol. 1995, 33, 83-89. [CrossRef]

8. Prairie, Y.T. Carbocentric limnology: Looking back, looking forward. Can. J. Fish. Aquat. Sci. 2008, 65, 543-548. [CrossRef]

9. Reynolds, C.S. A changing paradigm of pelagic food webs. Int. Rev. Hydrobio. 2008, 93, 517-531. [CrossRef]

10. Brett, M.T.; Arhonditsis, G.B.; Chandra, S.; Kainz, M.J. Mass flux calculations show strong allochthonous support of freshwater zooplankton production is unlikely. PLoS ONE 2012, 7, e39508. [CrossRef]

11. Brett, M.T.; Benjamin, M.M. A reassessment of lake phosphorus retention and the nutrient loading concept in limnology. Freshw. Biol. 2008, 53, 194-211.

12. Wetzel, R.G. Limnology, Lake and River Ecosystems, 3rd ed.; Academic Press: San Diego, CA, USA, 2001.

13. Lewis, W.M., Jr. Global primary production of lakes: 19th Baldi Memorial Lecture. Inland Waters 2011, 1, 1-28. [CrossRef]

14. von Wachenfeldt, E.; Tranvik, L.J. Sedimentation in Boreal Lakes-The Role of Flocculation of Allochthonous Dissolved Organic Matter in the Water Column. Ecosystems 2008, 11, 803-814. [CrossRef]

15. del Giorgio, P.A.; Cole, J.J. Bacterial growth efficiency in natural aquatic systems. Annu. Rev. Ecol. Syst. 1998, $29,503-541$. [CrossRef]

16. Olofsson, M.; Robertson, E.K.; Edler, L.; Arneborg, L.; Whitehouse, M.J.; Ploug, H. Nitrate and ammonium fluxes to diatoms and dinoflagellates at a single cell level in mixed field communities in the sea. Sci. Rep. 2019, 9, 1424. [CrossRef] [PubMed]

17. Tiselius, P.; Belgrano, A.; Andersson, L.; Lindahl, O. Primary productivity in a coastal ecosystem: A trophic perspective on a long-term time series. J. Plankton Res. 2015, 38, 1092-1102. [CrossRef]

18. Galloway, A.W.E.; Brett, M.T.; Holtgrieve, G.W.; Ward, E.J.; Ballantyne, A.P.; Burns, C.W.; Kainz, M.J.; Müller-Navarra, D.C.; Persson, J.; Ravet, J.L.; et al. A fatty acid based Bayesian approach for inferring diet in aquatic consumers. PLoS ONE 2015, 10, e0129723. [CrossRef] [PubMed]

19. Brett, M.T.; Müeller-Navarra, D.C. The role of highly unsaturated fatty acids in aquatic food web processes. Freshw. Biol. 1997, 38, 483-499. [CrossRef]

20. Klawonn, I.; Nahar, N.; Walve, J.; Andersson, B.; Olofsson, M.; Svedén, J.B.; Littman, S.; Whitehouse, M.J.; Kuypers, M.M.M.; Ploug, H. Cell-specific nitrogen- and carbon-fixation of cyanobacteria in a temperate marine system (Baltic Sea). Environ. Microbiol. 2016, 18, 4596-4609. [CrossRef]

21. Stoecker, D.K.; Hansen, P.J.; Caron, D.A.; Mitra, A. Mixotrophy in the marine plankton. Annu. Rev. Mar. Sci. 2017, 9, 311-335. [CrossRef]

22. Nielsen, J.M.; Clare, E.; Hayden, B.; Brett, M.T.; Kratina, P. Diet tracing in ecology: Method comparison and selection. Meth. Ecol. Evol. 2017, 9, 278-291. [CrossRef]

23. Glibert, P.M.; Middelburg, J.J.; McClelland, J.W.; Vander Zanden, M.J. Stable isotope tracers: Enriching our perspectives and questions on sources, fates, rates, and pathways of major elements in aquatic systems. Limnol. Oceanogr. 2018, 9999, 1-32. [CrossRef]

24. Hungate, B.A.; Mau, R.L.; Schwartz, E.; Caporaso, J.G.; Dijkstra, P.; van Gestel, N.; Koch, B.J.; Liu, C.M.; McHugh, T.A.; Marks, J.C.; et al. Quantitative Microbial Ecology through Stable Isotope Probing. Appl. Envir. Microbiol. 2015, 81, 7570-7581. [CrossRef]

25. Vadeboncoeur, Y.; Power, M.E. Attached algae: The cryptic base of inverted trophic pyramids in freshwaters. Annu. Rev. Ecol. Evol. Syst. 2017, 48, 255-279. [CrossRef]

26. Power, M.E. Resource Enhancement by Indirect Effects of Grazers: Armored Catfish, Algae, and Sediment. Ecology 1990, 71, 897-904. [CrossRef]

27. André, E.R.; Hecky, R.E.; Duthie, H.C. Nitrogen and phosphorus regeneration by cichlids in the littoral zone of Lake Malawi, Africa. J. Great Lakes Res. 2003, 29, 190-201. [CrossRef]

28. Munubi, R.N.; McIntyre, P.B.; Vadeboncoeur, Y. Do grazers respond to or control food quality? Cross-scale analysis of algivorous fish in littoral Lake Tanganyika. Oecologia 2018, 188, 889-900. [CrossRef] [PubMed] 
29. Power, M.E. Habitat Quality and the Distribution of Algae-Grazing Catfish in a Panamanian Stream. J. Anim. Ecol. 1984, 53, 357-374. [CrossRef]

30. Mittelbach, G.G.; Osenberg, C.W.; Leibold, M.A. Trophic relations and Ontogenetic niche shifts in Aquatic Ecosystems. In Size Structured Populations; Ebenman, B., Persson, L., Eds.; Springer: Berlin, Germany, 1988; pp. 1-17.

31. Vander Zanden, M.J.; Chandra, S.; Park, S.-K.; Vadeboncoeur, Y.; Goldman, C.R. The relative efficiencies of benthic and pelagic trophic pathways in a subalpine lake. Can. J. Fish. Aquat. Sci. 2006, 63, 2608-2620. [CrossRef]

32. Vadeboncoeur, Y.; McCann, K.; Zanden, M.; Rasmussen, J. Effects of multi-chain omnivory on the strength of trophic control in lakes. Ecosystems 2005, 8, 682-693. [CrossRef]

33. James, M.R.; Hawes, I.; Weatherhead, M.; Carmen Stanger, C.; Gibbs, M. Carbon flow in the littoral food web of an oligotrophic lake. Hydrobiologia 2000, 441, 93-106. [CrossRef]

34. Moore, J.W. Some factors effecting algal consumption in subarctic Ephemeroptera, Plecoptera and Simuliidae. Oecologia 1977, 27, 261-273. [CrossRef]

35. Scharnvaeber, K.; Syväranta, J.; Hilt, S.; Brauns, M.; Vanni, M.J.; Brothers, S.; Köhler, J.; Knežević-Jarić, J.; Mehner, T. Whole-lake experiments reveal the fate of terrestrial particulate organic carbon in benthic food webs of shallow lakes. Ecology 2014, 95, 1496-1505. [CrossRef] [PubMed]

36. Guo, F.; Kainz, M.J.; Valdez, D.; Sheldon, F.; Bunn, S.E. High-quality algae attached to leaf litter boost invertebrate shredder growth. Freshw. Sci. 2016, 35, 1213-1221. [CrossRef]

37. Cashman, M.J.; Harvey, G.L.; Wharton, G.; Bruno, M.C. Wood mitigates the effect of hydropeaking scour on periphyton biomass and nutritional quality in semi-natural flume simulations. Aquat. Sci. 2017, 79, 459-471. [CrossRef]

38. Kupferberg, S.J.; Marks, J.C.; Power, M.E. Effects of variation in natural algal and detrital diets on larval anuran (Hyla regilla) life-history traits. Copeia 1994, 1994, 446-457. [CrossRef]

39. Power, M.E.; Lowe, R.; Furey, P.; Welter, J.; Limm, M.; Finlay, J.; Bode, C.; Chang, S.; Goodrich, M.; Sculley, J. Algal mats and insect emergence in rivers under Mediterranean climates: Towards photogrammetric surveillance. Freshw. Biol. 2008, 54, $2101-2115$. [CrossRef]

40. Torres-Ruiz, M.; Wehr, J.D.; Perrone, A.A. Trophic relations in a stream food web: Importance of fatty acids for macroinvertebrate consumers. J. North. Am. Benthol. Soc. 2007, 26, 509-522. [CrossRef]

41. Guo, F.; Kainz, M.J.; Sheldon, F.; Bunn, S.E. The importance of high-quality algal food sources in stream food webs-current status and future perspectives. Freshw. Biol. 2016, 61, 815-831. [CrossRef]

42. Glibert, P.M.; Goldman, J. Rapid ammonium uptake by marine phytoplankton. Mar. Biol. Lett. 1981, 2, 25-31.

43. Canfield, D.E.; Glazer, A.N.; Falkowski, P.G. The evolution and future of the nitrogen cycle. Science 2010, 330, 192-196. [CrossRef]

44. Olofsson, M.; Karlberg, M.; Lage, S.; Ploug, H. Phytoplankton community composition and primary production in the tropical tidal ecosystem, Maputo Bay (the Indian Ocean). J. Sea Res. 2017, 125, 18-25. [CrossRef]

45. Klawonn, I.; Bonaglia, S.; Whitehouse, M.J.; Littmann, S.; Tienken, D.; Kuypers, M.M.M.; Brüchert, V.; Ploug, H. Untangling hidden nutrient dynamics: Rapid ammonium cycling and single-cell ammonium assimilation in marine plankton communities. ISME J. 2019, 13, 1960-1974. [CrossRef]

46. Musat, N.; Foster, R.; Vagner, T.; Adam, B.; Kuypers, M.M.M. Detecting metabolic activities in single cells, with emphasis on nanoSIMS. FEMS Microb. Rev. 2012, 36, 486-511. [CrossRef]

47. Bergkvist, J.; Klawonn, I.; Whitehouse, M.J.; Lavik, G.; Brüchert, V.; Ploug, H. Turbulence simultaneously stimulates small- and large-scale $\mathrm{CO}_{2}$ sequestration by chain-forming diatoms in the sea. Nat. Comms. 2018, 9, 3046. [CrossRef] [PubMed]

48. Clift, R.; Grace, J.R.; Weber, M.E. Bubbles, Drops, and Particles; Acad. Press: New York, NY, USA, 1978.

49. Seymour, J.R.; Amin, S.A.; Raina, J.-B.; Stocker, R. Zooming in on the phycosphere: The ecological interface for phytoplanktonbacteria relationship. Nat. Microb. 2017, 2, 17065. [CrossRef] [PubMed]

50. Glibert, P.M.; Wilkerson, F.P.; Dugdale, R.-C.; Raven, J.A.; Dupont, C.L.; Leavitt, P.R.; Parker, A.E.; Burkholder, J.M.; Kana, R.M Pluses and minuses of ammonium and nitrate uptake and assimilation by phytoplankton and implications for productivity and community composition, with emphasis on nitrogen-enriched conditions. Limnol. Oceanogr. 2016, 61, 165-197. [CrossRef]

51. Ward, B.B. Nitrification: An introduction and overview of the state of the field. In Nitrification; Ward, B.B., Arp, D.J., Klotz, M.G., Eds.; ASM Press: Washington, DC, USA, 2011; pp. 3-8.

52. Jetten, M.S.M.; Strous, M.; van de Pas-Schoonen, K.T.; Schalk, J.; van Dongen, U.G.J.M.; can de Graaf, A.A.; Logemann, S.; Muyzer, G.; van Loosdrecht, M.C.M.; Kuenen, J.G. The anaerobic oxidation of ammonium. FEMS Microbiol. Rev. 1998, 22, $421-437$. [CrossRef] [PubMed]

53. Zakem, E.; Al-Haj, A.; Church, M.J.; van Dijken, G.L.; Dutkiewicz, S.; Foster, S.Q.; Fulweiler, R.W.; Mills, M.M.; Follows, M.J. Ecological control of nitrite in the upper ocean. Nat. Comms. 2018, 9, 1206. [CrossRef]

54. Steinberg, P.D.; Brett, M.T.; Bechtold, J.S.; Richey, J.E.; Porensky, L.; Smith, S.N. The influence of watershed characteristics on nitrogen export to and marine fate in Hood Canal, Washington, USA. Biogeochemistry 2011, 106, 415-433. [CrossRef]

55. Marchant, H.K.; Mohr, W.; Kuypers, M.M.M. Recent advances in marine N-cycle studies using ${ }^{15}$ N labeling methods. Curr. Opin. Biotechnol. 2016, 41, 53-59. [CrossRef]

56. Robertson, E.K.; Bartoli, M.; Brüchert, V.; Dalsgaard, T.; Hall, P.O.J.; Hellemann, D.; Hietanen, S.; Zilius, M.; Conley, D.J. Application of the isotope pairing technique in sediments: Use, challengers, and new directions. Limnol. Oceanogr. Methods 2019, 17, 112-136. [CrossRef] 
57. Massé, S.; Botrel, M.; Walsh, D.A.; Maranger, R. Annual nitrification dynamics in a seasonally ice-covered lake. PLoS ONE 2019, 14, e0213748. [CrossRef] [PubMed]

58. Könneke, M.; Bernhard, A.E.; de la Torre, J.R.; Walker, C.B.; Waterbury, J.B.; Stahl, D.A. Isolation of an autotrophic ammoniaoxidizing marine archaeon. Nature 2005, 437, 543-546. [CrossRef] [PubMed]

59. Martens-Habbena, W.; Berube, P.M.; Urakawa, H.; de la Torre, J.R.; Stahl, D.A. Ammonia oxidation kinetics determine niche separation of nitrifying Archaea and Bacteria. Nature 2009, 461, 976-979. [CrossRef] [PubMed]

60. Meyer-Jacob, C.; Michelutti, N.; Paterson, A.M.; Cumming, B.F.; Keller, W.B.; Smol, J.P. The browning and re-browning of lakes: Divergent lake-water organic carbon trends linked to acid deposition and climate change. Sci. Rep. 2019, 9, 16676. [CrossRef] [PubMed]

61. Monteith, D.T.; Stoddard, J.L.; Evans, C.D.; de Wit, H.A.; Forsius, M.; Hogåsen, T.; Wilander, A.; Sjelkvåle, B.L.; Jeffries, D.S.; Vuorenmaa, J.; et al. Dissolved organic carbon trends resulting from changes in atmospheric deposition chemistry. Nature 2007, 450, 537-540. [CrossRef]

62. Garmo, Ø.A.; Skjelkvåle, B.L.; de Wit, H.A.; Colombo, L.; Curtis, C.; Fölster, J.; Hoffmann, A.; Hruska, J.; Hogåsen, T.; Jeffries, D.S.; et al. Trends in surface water chemistry in acidified areas in Europe and North America from 1990 to 2008. Water Air Soil Poll. 2014, 225, 1880. [CrossRef]

63. Cavicchioli, R.; Ripple, W.J.; Timmis, K.N.; Azam, F.; Bakken, L.R.; Baylis, M.; Behrenfeld, M.J.; Boetius, A.; Boyd, P.W.; Classen, A.T.; et al. Scientists' warning to humanity: Microorganisms and climate change. Nat. Rev. Microb. 2019, 17, 569-586. [CrossRef]

64. Hansell, D.A. Recalcitrant dissolved organic carbon fractions. Annu. Rev. Mar. Sci. 2013, 5, 421-445. [CrossRef] [PubMed]

65. Azam, F.; Fenchel, T.; Field, J.G.; Gray, I.S.; Meyerreil, L.A.; Thingstad, F. The ecological role of water-column microbes in the sea. Mar. Ecol Prog Ser. 1983, 10, 257-263. [CrossRef]

66. Arandia-Gorostidi, N.; Weber, P.K.; Alonso-Sáez, L.; Morán, X.A.G.; Mayali, X. Elevated temperature increases carbon and nitrogen fluxes between phytoplankton and heterotrophic bacteria through physical attachment. ISME J. 2016, 11, 641-650. [CrossRef] [PubMed]

67. Durham, B.P.; Sharma, S.; Luo, H.; Smith, C.B.; Amin, S.A.; Bender, S.J.; Dearth, S.P.; Van Mooy, B.A.S.; Campagna, S.R.; Kujawinski, E.B.; et al. Cryptic carbon and sulfur cycling between surface ocean plankton. Proc. Natl. Acad. Sci. USA 2015, 12, 453-457. [CrossRef] [PubMed]

68. Amin, S.A.; Hmelo, L.R.; van Tol, H.M.; Durham, B.P.; Carlson, L.T.; Heal, K.R.; Morales, R.L.; Berthiaume, C.T.; Parker, M.S.; Djunaedi, B.; et al. Interaction and signaling between a cosmopolitan phytoplankton and associated bacteria. Nature 2015, 522, 98-101. [CrossRef] [PubMed]

69. Hipsey, M.R.; Gal, G.; Arhonditsis, G.B.; Carey, C.C.; Elliott, J.A.; Frassl, M.A.; Janse, J.H.; Mora, L.; Robson, B.J. A system of metrics for the assessment and improvement of aquatic ecosystem models. Environ. Model. Softw. 2020, 128, 104697. [CrossRef] 